\title{
THE DOUBLE-MOVEMENT MODEL OF FORGIVENESS IN BUDDHIST AND CHRISTIAN RITUALS
}

\author{
PAUL REASONER \& CHARLES TALIAFERRO
}

Bethel University

St. Olaf College

\begin{abstract}
We offer a model of moral reform and regeneration that involves a wrong-doer making two movements: on the one hand, he identifies with himself as the one who did the act, while he also intentionally moves away from that self (or set of desires and intentions) and moves toward a transformed identity. We see this model at work in the formal practice of contrition and reform in Christian and Buddhist rites. This paper is part of a broader project we are undertaking on the philosophy of forgiveness.
\end{abstract}

\section{INTRODUCTION}

Many questions swirl around in the general vicinity of forgiveness. Can one have a duty to forgive someone? When might forgiveness be a virtue or vice? When does forgiveness conflict with justice? Must one confess and apologize if one is to receive forgiveness? In the course of a broader book project, we are developing what we are calling "the double-movement model" of forgiveness that will address these and other questions. This model draws from philosophical and religious analyses, historical examples, and literary sources. While we want our conceptions to be grounded in historical contexts, in the end, we wish to defend a normative position. Part of working toward a defensible analysis of forgiveness includes learning from forgiveness rituals and asking how they should inform a philosophy of forgiveness.

In this essay we focus on texts of confession and forgiveness from the Buddhist and Christian traditions. Forgiveness as understood and practiced in these texts and rituals will be set against the preliminary sketch of "the double-movement model" of forgiveness in part to test its viability as a model. This essay is thus an exploratory study to see if there are structural similarities in their respective conceptions of

European Journal for Philosophy of Religion i (2009), PP. 27-39 
confession and forgiveness. If there are differences, are those differences substantive conceptually? Our tentative thesis is that while the general structure is similar in the Buddhist and Christian rituals and the texts considered here, i.e., both map well onto the double-movement model of forgiveness, the differences in emphasis that do appear are due chiefly to the radically different ontological commitments of the two traditions. Analysis of these rituals and texts on forgiveness suggests two formulations of the concept of forgiveness-relational forgiveness and regenerative forgiveness.

\section{The DOUbLE-MOVEMENT MODEL OF FORgIVENESS}

First, consider the double-movement model of forgiveness. In brief, the model defends an analysis of forgiveness requiring both the one seeking forgiveness and the one offering forgiveness to perform a double-movement in terms of each person's (respective) self-identification. The one seeking forgiveness must return to and own the fault (confession, authentic display of remorse, sorrow for the wrong committed), while at the same time moving from self-identification with the self who has committed the fault to a new self-identity which repudiates the self who commits such faults (a form of self-division). The new self-identification is a form of repentance which seeks reform and restitution. In a similar movement, the forgiver must recognize the identity of the self who has perpetrated the fault while seeing the guilty person in a new light - as capable of possessing a new self-identity. This is accomplished in part by an empathetic awareness on the part of the forgiver that one is capable of committing acts which would put oneself in need of forgiveness.

In passing we note that, of course, the full scope of this model may fail to be fulfilled in concrete instances in a number of ways. Confession may be made and forgiveness asked for, but the one harmed may not offer forgiveness. Forgiveness may be given even though there is no repentance. Or, forgiveness may be offered without the forgiver making the doublemovement internally. The wrongdoer may ask for forgiveness without properly owning the fault and thus minimizing the significance of the wrong... and so on. While the full scope of the model may fail to be 
fulfilled, we argue that where either the wrongdoer or the one wronged takes his or her part seriously, something good has been accomplished even though it is only a partial good to be sure.

Before examining Buddhist and then Christian forgiveness rituals, let us consider a challenge to our current project.

\section{A Preliminary Worry}

Consider a preliminary worry and puzzle about the nature and extent of forgiveness in Buddhism. One might object that the formulation of the double-movement model with its emphasis on self-identity and alterations in self-identity (self-division) is simply assuming too substantial a notion of selves to be applicable in Buddhism. One might ask, "Aren't we supposed to get past all that in Buddhism? What about emptiness?" And even more fundamentally, is forgiveness that central of an issue in Buddhism? One can check the indexes of many texts on Buddhism and not even find forgiveness and repentance listed. In fairly standard accounts of Buddhism we read statements like the following:

The evil in man's life is man-made and, therefore, eradicable by man, without outside interference. In Buddhism, there is no such thing as original sin, no innate depravity, and no one is fore-ordained to be doomed. There is, likewise, no atonement and no forgiveness of sins, because there is no one who can forgive, and because a transgression, once committed, cannot be redeemed. ${ }^{1}$

Statements such as these suggest that our project here is completely misguided. And yet, in a recent book, His Holiness the Dalai Lama preaches forgiveness [in the context of discussing forgiveness and spiritual progress]:

"It's [forgiveness] crucial. It's one of the most important things. It can change one's life. To reduce hatred and other destructive emotions, you must develop their opposites-compassion and kindness. If you have strong compassion, strong respect for others, then forgiveness is much easier. Mainly for this

${ }^{1}$ G. P. Malalasekera, "The Status of the Individual in Theravada Buddhism," Philosophy East and West Vol. I4, No. 2 (1964): 152. 
reason: I do not want to harm another. Forgiveness allows you to be in touch with these positive emotions. This will help with spiritual development." ${ }^{2}$

Elsewhere in the same work, he ties forgiveness to interdependence or codependent origination. ${ }^{3}$ So, on the one hand, forgiveness is said to be non-existent in Buddhism; on the other hand it is tied to spiritual development in general and central Buddhist doctrines such as codependent origination in particular.

How to resolve this apparent difference? The Dalai Lama seems to be speaking of the role that forgiveness can play in one's own spiritual growth-not holding grudges and refraining from anger have positive effects on emotions and even physical health. This forgiveness is based on an awareness of the interdependence between oneself and the other. ${ }^{4}$ This fits well with the double-movement model on the side of the forgiver. In agreement with Malalasekera, the forgiveness taught by the Dalai Lama affirms the emptiness of the self and the resulting generation of compassion due to an awareness of interdependence. Malalasekera assumes that forgiveness implies a substance view of selves and (perhaps) some type of ontological transaction. Since the law of karma with its causal effects must not be abrogated, there is no forgiveness for Malalasekera since such karmic outflows cannot be [magically] wiped away. This suggests perhaps two different core conceptions of forgiveness - relational forgiveness and regenerative forgiveness. We explicate these below.

\section{A Buddhist EXAMPLe: PRATIMoKsa}

Another approach to the preliminary worry is to note that forgiveness and reconciliation play central roles in early Buddhist rituals and texts. The Pratimoksa, the earliest set of rules for monastic discipline in Buddhism, was typically recited on days one and fifteen of the lunar calendar by the community of monks. While the oldest parts of the Pratimoksa

${ }^{2}$ Dalai Lama, with Victor Chan, The Wisdom of Forgiveness (New York: Riverhead Books, 2004), 73.

${ }^{3}$ Dalai Lama, The Wisdom of Forgiveness, III.

${ }^{4}$ See an example of this awareness of forgiveness as interdependence in the case of vandalism at a Vietnamese Buddhist temple in Boston in Richard Higgins, "Mindful Suffering," Christian Century II8.29 (October 24-3I, 200I): 9-IO. 
text probably date from 500-450 B.C.E., the final form of some of its earliest versions can be dated to around 400 B.C.E. ${ }^{5}$ It exists in variant forms in the various Buddhist sects and schools in India, Tibet, and China. ${ }^{6}$ Roughly it contains a set of rules for proper living in monastic life, including stipulation of punishments for particular actions and formulae for confession, forgiveness, and restitution. The ritual recitation of the Pratimoksa twice monthly is a type of communal confession and affirmation. It begins with praise, followed by instructions from the abbot or leader of the ritual as to how responses are to be made when various categories of rules are recited (we are quoting here from the "The Pratimoksa Sutra of the Mahasamghikas," in Prebish):

O Venerable Ones, I will recite the Pratimoksa Sutra. I will speak, and you should listen to it obediently and aptly, and reflect on it. For whom there may be a fault, let him confess it. If there is no fault, [one] should be silent. By being silent, I will know the Venerable Ones are completely pure. Just as, $\mathrm{O}$ Venerable Ones, there is an explanation for a monk questioned individually, so it will be proclaimed in this or that form in the assembly of monks up to the third time. For whatever monk, being questioned in this way up to the third time in the assembly of monks, who does not reveal an existing fault which is remembered, there is the speaking of a deliberate lie. The speaking of a deliberate lie has been declared by the Blessed One to be an obstructive condition. Therefore an existing fault should be revealed by a fallen monk, remembering [the offense and] hoping for purity. Having revealed it, there will be comfort for him, but by not revealing it, there is none. ${ }^{7}$

In general, after each category, the monks will be asked three times if they have anything to confess; silence will be taken to mean that they are all pure. The categories include precepts whose violation requires expulsion, suspension, and other consequences, confession and forfeiture, confession and absolution, and so on. Expulsion from the community

5 Prebish, Charles S. “The Pratimoksa Puzzle: Fact versus Fantasy," Journal of the American Oriental Society Vol. 94, No. 2 (1974): I7I.

${ }^{6}$ Much useful information about confession and repentance groups (including revivals of Pratimoksa practice in China) can be found in Wu, Pei-Yi, "Self-Examination and Confession of Sins in Traditional China," Harvard Journal of Asiatic Studies Vol. 39, No. I (I979), 5-38.

${ }^{7}$ Charles S. Prebish, Buddhist Monastic Discipline (University Park and London: The Pennsylvania State University Press, I975), 48, 50. 
of monks is the punishment for breaking any of the first four teachings which the text summarizes (after more detailed description) as "(I) sexual intercourse, (2) taking what is not given, (3) slayer of one having human form, and (4) asserting that one may have superhuman faculties." ${ }^{\prime} \mathrm{We}$ note parenthetically that the Dalai Lama in an interview with Victor Chan recorded in the book The Wisdom of Forgiveness, when questioned about his own spiritual experiences, takes great pains to make sure that he is not understood to be claiming more than exactly what he says. $\mathrm{He}$ interjects that he would have to stop being a monk if he were to tell a lie about his spiritual experiences. This appears to be a straightforward reference to (4) in the Pratimoksa. ${ }^{9}$

After the initial four teachings, a set of thirteen are given where faults in these areas can result in temporary suspension from the community. The last four (of this set of thirteen) allow for admonitions up to three times to bring the monk at fault to the state of confession. Faults in this set of thirteen include (9) falsely accusing a brother monk of committing one of the four initial offenses which are punishable by expulsion. At the end of this set of thirteen, the leader recites the typical formula of asking three times if all are pure, and the monks assert by their silence that they are pure in this category as well. However, due to their special interest, we cite briefly several comments made by the leader just before the three-fold purity call is made (using a more modern translation of the Pratimoksa based on a Chinese version of the text):

If One of this Sangha has broken these Dharmas, willfully concealing it, such a one should be placed in isolation for a period equal to the period of concealment; willingly or unwillingly should such a one be so confined. When the isolation period is ended, let such a one spend six nights undergoing joyful confession, repentance and reflection. When these six nights are completed, then with clear mind such a one should be summoned and, in accord with this Dharma, should be absolved. Twenty Pure Ones of this Sangha may absolve such a one; however, if there is but one less than twenty, there is no absolution and those who would conduct absolution with less that [sic] the full number shall be called blameworthy. (A Pratimoksa Sutra for Western Lands).

\footnotetext{
${ }^{8}$ Prebish, Buddhist Monastic Discipline, 52.

9 Dalai Lama, The Wisdom of Forgiveness, 185.
} 
At a number of points, elements within the ritual of the Pratimoksa line up with the double-movement model of forgiveness. From the side of the one needing forgiveness, a vital element in this ritual is confession (owning that it is you engaging in the wrongful conduct). Confession in itself, in this context, is an indication that one wants to rejoin the community (hence a self-identification with a self who will no longer perpetrate the fault). Confession is even described as "joyful" which can be construed as indicating that the identification with the new self signals a radical shift.

An intriguing aspect of the punishment phase is that one is to be confined for a length of time equal to the time of wrongful concealment. Perhaps the insight here is that the length of time of concealment corresponds to how firmly one has identified with the self who is guilty of the fault. An equal length of time may be necessary to rid one's thinking of that self-identification and formulate a new self-identification as one who rejects such things. (Parenthetically, note that Dante has some of the late repentant souls in ante-purgatory also waiting for a length of time equal to the time on earth during which they failed to make confession (make their peace with the church), before they are allowed to start climbing Mt. Purgatory). ${ }^{10}$

These passages do not focus as much on the side of the one who forgives. However, we note in passing the communal emphasis - twenty monks must be present and agree for absolution to take place. It appears that it is the monks themselves who perform the rite of absolution. In this context, a community of monks (not an individual monk) can be identified as the forgiver in the double-movement model.

One curiosity in the Pratimoks ritual is that nothing in the text indicates that actual confessions are expected within the ritual. For example, even though the monks are asked three times if they have faults at the end of each section, the text has no provision within the ritual for how the ritual is to go if someone were to confess. This line of thought might be easily dismissed as an argument from silence, except that there is a brief passage near the beginning of the Pratimoksa which describes all those assembled as pure ("And here no one is unordained, disposed to passion,

${ }^{10}$ Dante Alighieri, The Divine Comedy: Purgatory, Translated by Mark Musa (New York: Penguin, I98I), Canto IV.I27-I32. 
a matricide, a patricide, the murderer of an arhant, a schism-maker in the samgha..." $)^{11}$. So, one might characterize the Pratimoksa ritual as a confession and forgiveness ritual which is a seal of what has already been accomplished prior to the ritual. Prebish offer historical support for this interpretation noting that the Buddha once refused to take part in a Pratimoksa ritual because an impure monk was present. ${ }^{12}$

We now shift to an example from the Christian tradition.

\section{A Christian example: The RULE of $S$ t. Benedict}

The Rule of St. Benedict, ${ }^{13}$ dating from the $6^{\text {th }}$ century C.E., is still followed widely and is the model for many later monastic rules (although it itself is drawn in part from earlier rules). ${ }^{14}$ Before offering several passages from The Rule of St. Benedict, consider two chapters which focus on faults and what is to be done about them:

Chapter 23: Excommunication for faults

If a brother is found to be stubborn, disobedient, proud or a murmurer, or at odds with the Holy Rule, or scornful of his elders' directions, he should be admonished by his superiors-in accordance with the Lord's injunction-twice in private. If even then he does not make amends, let him be reproved in public. However, if there is still no change, he shall be subject to excommunication, if he understands what kind of punishment this is. If he is obstinate he shall undergo corporal punishment.

11 Prebish, Buddhist Monastic Discipline, 46.

${ }_{12}$ Prebish, Buddhist Monastic Discipline, 25.

13 The Rule of St. Benedict, Translated by Anthony C. Meisel and M. L. del Mastro (New York: Doubleday, I975).

${ }_{14}$ There is one difficulty with using The Rule of St. Benedict as an example. While it is a close comparison to the Pratimoksa in that it contains rules for monastic life, perhaps it lacks a point of comparison at the ritual level. While it has often been recited and studied in monasteries (indeed Chapter 66 instructs that the Rule is to be read frequently in the community), the recitation of the Rule itself has not, as far as we know, functioned as arite of confession and forgiveness. It does describe how confession is to be encouraged and forgiveness effected. For a more complete ritual of forgiveness, one might need to look elsewhere. 
Chapter 24: The measure of excommunication

The severity of excommunication as a punishment depends upon the nature of the violation, which is to be judged by the abbot. For minor faults a brother should be kept from eating at the common table. This exclusion means that he shall not intone a psalm or antiphon or read a lesson in the oratory, until he makes his amends. His meals will be taken alone, after the others have finished. If the brothers eat at the sixth hour, he will do so at the ninth; if they eat at the ninth, he will eat in the evening. He will continue to behave like this until he has been granted pardon by means of some suitable act of atonement. (The Rule of St. Benedict, 70-71).

Here again, aspects of the double-movement model of forgiveness are clearly present. In Chapter 23, confession (owning up to being the self who has perpetrated the fault) is so necessary that one may be admonished three times, placed outside the fellowship of the community, and even suffer corporal punishment if one fails to make confession. Other passages (not quoted above) illustrate the empathetic understanding of those on the forgiving side since they are to treat the guilty party with care and concern as if the latter were sick, with the implication that we are all sick at times (Chapter 27).

Elsewhere (Chapter 13), the Rule states that Lauds and Vespers are to end with the Lord's Prayer, specifically so that the monks will have the injunction to forgive on their minds. "Forgive us our trespasses, as we forgive those who trespass against us."To be forgiven one must be active in forgiving others. This brief phrase ties together tightly the forgiver and the one forgiven in the double-movement model.

The Rule also contains instructions for public penance when late for services (Chapter 43), as well as prostrations for particular faults. These are clearly designed to aid the one at fault in developing a new identity (these acts of penance/punishment are necessary so that the monk "will fare better in the future," or "until he reforms and makes satisfaction"-Chapter 43).

Aspects of the double-movement model are clearly displayed here as well. We now return to some fundamental conceptions of forgiveness. 


\section{Relational Forgiveness and Regenerative Forgiveness}

Might it be possible that in both traditions, there is an awareness of two possible meanings of forgiveness? The communal necessity of forgiveness might fall under the heading of relational forgiveness. All must be well between members of the community for the community to function. Rituals of forgiveness are necessary to insure the communal bond. In addition, the examples we looked at add something to the double-movement model. This concept of relational forgiveness implies that the new identity to be owned by the one in need of forgiveness is not merely a morally purified identity; it is also a communal identity. ("I am not simply seeing myself as one who is pure with regard to X; I am a member of the samgha which includes that I am pure with regard to X.")

On the other hand, the appeal to a concept of forgiveness where deeper ontological change takes place in the order of things might be called regenerative forgiveness, for here some change in status is imputed to the individual or understood to have happened in the individual. Both traditions, in the examples we have looked at, focus on relational forgiveness. Some Buddhist commentators expressly reject regenerative forgiveness given their understanding of the (non-substantial) nature of things and the law of karma. ${ }^{15}$ The comment by the Dalai Lama noted earlier focuses on forgiveness as part of ongoing spiritual work that one does for oneself-ridding oneself of hateful thoughts and intentions. He says little about the effect this has on the one being forgiven. Even in the Rule of St. Benedict, where a theology of regenerative forgiveness is affirmed, the two seem to be separated - one may fail to achieve relational forgiveness but still hold out hope for regenerative forgiveness due to the mercy of God (see Chapter 29 on readmitting brothers who leave the community- "If he leaves again, he may re-enter a third time. After that he will be forever forbidden re-entry" (The Rule of St. Benedict, 74). Similarly, in terms of relational forgiveness, the Pratimoksa also has recourse to expulsion.

In later Buddhist contexts, regenerative forgiveness (perhaps suitably redefined as karmic changes for the individual outside of the individual's

15 Further discussion of comparative puzzles related to karma and grace can be found in Stephen T.Davis" "Karma and Grace," in The Redemption: An Interdisciplinary Symposium on Christ as Redeemer, ed. Stephen T. Davis, Daniel Kendall, SJ, and Gerald O'Collins, SJ (Oxford: Oxford University Press, 2004), 235-253. 
stream of karmic outflows) can be entertained through the compassion of bodhisattvas such as Amida in Pure Land Buddhism. Of course even in this example, the regenerative forgiveness is at one remove from change in the ultimate karmic order, since the bodhisattva must have accrued enough karma to overcome the negative karma of the one needing forgiveness. ${ }^{16}$

\section{Tentative Conclusions}

Comparisons of the Buddhist and Christian examples reveal some striking similarities and confirmation of the double-movement model of forgiveness.

First, both have the optimal case of confession (the first stage in self-division): the Pratimoksa continually, throughout the ritual, gives the option for confession, while The Rule of St. Benedict describes a number of ways to encourage confession for the reform of the brother.

Second, both entertain the idea of placing the guilty party in isolation, perhaps to encourage and cement self-division, or the use of punishment to bring the guilty party to a place where self-division is contemplated as a live option. In both traditions, separation from the community is a significant punishment (note especially The Rule of St. Benedict on eating at table). Separation from community, a forced self-division from one's identity as a member, in good standing, of the community, places the focus on the guilty party as disruptive of the community and highlights that this disruption must be addressed before the individual in question and the community can be whole again.

Third, as noted above, one feature of the punishment phase in the Pratimoksa dictates that the length of confinement is to be equal to the length of time the fault was concealed. The Rule of St. Benedict hints at

${ }_{16}$ The Eighteenth Vow of Dharmakara (who becomes Amida Buddha) in The Larger Sutra on Amitayus (also knows as The Larger Sukbavativyuba Sutra) makes the need for accrual of merit clear: „If, when I attain Buddhahood, sentient beings in the lands of the ten directions who sincerely and joyfully entrust themselves to me, desire to be born in my land, and think of me even ten times should not be born there, may I not attain perfect enlightenment. Excluded, however, are those who commit the five grave offenses and abuse the Right Dharma" (The Three Pure Land Sutras, r6). When sentient beings call on his name, Amida is able to preserve the law of karma by using his surplus merit to offset their damaging karmic outflows so that he can take them to the Pure Land at their death. 
something similar; even everyday mistakes are to be more severely punished if they are hidden (Chapter 46). While the double-movement model of forgiveness asserts that a self-identification and self-division must take place, the rituals studied here make clear that the movement may not be so simple, that it may need some external persuasion, and that it may take time to solidify the new self-identification. This has been instructive.

Fourth, in comparing Buddhist and Christian thought on regenerative forgiveness, one expects to see a difference in emphasis given the different ontological commitments. In the forms of Buddhism which do not recognize "other power," the notion of regeneration seems less appropriate since any improvement is made by oneself (even as one's sense of self diminishes). One might prefer to speak of self-correction. In the forms of Buddhism which do recognize or appeal to "other power" (tariki), such as Pure Land Buddhism, a difference with Christianity might still be noted given that Amida Buddha has to have accrued enough karmic merit to overcome the negative karmic outflows of any person who calls on his name with faith. Here the "regeneration" is a re-direction of karmic streams. So, historically Pure Land was the "easy path" for those unable or unwilling to attempt the traditional (long series of rebirths) method of achieving enlightenment in earlier forms of Buddhism. However, Amos Yong has suggested that even here, the parallel with Christian regenerative forgiveness may be closer than appears at first sight, since in Christian thought we have "the Pauline idea that the second Adam has to accomplish what the first Adam failed to do, which is to live that perfect holy life, and it is this life (the holy karma) which enables Jesus to be the sacrificial lamb through whom regenerative forgiveness is made available to others (those laboring under the negative karma of the first Adam)" (Yong, personal communication, January 9, 2006).

This has been only an initial exploration into forgiveness rituals. We welcome suggestions of other rituals to be studied and insights into how to make their analyses more fruitful, as we work toward a comprehensive inter-disciplinary philosophy of forgiveness. ${ }^{17}$

${ }^{17}$ Paul Reasoner presented this paper at the Ritual Studies Group and Ethics Section meeting at the American Academy of Religion (November 2005) and at the Central Division Meeting of the Society of Christian Philosophers (Union University, TN, April 2008). Both Reasoner and Taliaferro are grateful to comments from many at those sessions, and particularly thank William LaFleur (responding at the AAR session), Robert Roberts, and Amos Yong. 


\section{BibLIOGRAPHY}

Dalai Lama, His Holiness, with Victor Chan. The Wisdom of Forgiveness. New York: Riverhead Books, 2004.

Dante, Alighieri. The Divine Comedy: Purgatory. Translated by Mark Musa. New York: Penguin, I98r.

Davis, Stephen T. "Karma and Grace." In The Redemption: An Interdisciplinary Symposium on Christ as Redeemer, edited by Stephen T. Davis, Daniel Kendall, SJ, and Gerald O'Collins, SJ, 235-253. Oxford: Oxford University Press, 2004.

Higgins, Richard. "Mindful Suffering." Christian Century II8.29 (October 24-3I, 200I): 9-Io.

Inagaki, Hisao, trans. (with Harold Stewart). The Three Pure Land Sutras. Revised Second Edition. Berkeley: Numata Center for Buddhist Translation and Research, 2003.

Malalasekera, G. P. "The Status of the Individual in Theravada Buddhism.” Philosophy East and West Vol. I4, No. 2 (July, I964): I45-I56.

A Pratimoksa Sutra for Western Lands. http://www.dragonflower.org/pratimoksa.html

Prebish, Charles S. Buddhist Monastic Discipline. University Park and London: The Pennsylvania State University Press, I975.

Prebish, Charles S. "The Pratimoksa Puzzle: Fact versus Fantasy." Journal of the American Oriental Society Vol. 94, No. 2 (April-June, I974): I68-I76.

The Rule of St. Benedict. Translated by Anthony C. Meisel and M. L. del Mastro. New York: Doubleday, I975.

Wu, Pei-Yi. "Self-Examination and Confession of Sins in Traditional China." Harvard Journal of Asiatic Studies. Vol. 39, No. I (June, I979): 5-38. 